\title{
Comparison Study of Foreign Tourist Preferences in Choose The Attributes of Tourism Destination Pre and Post Natural Disaster
}

\author{
Ni Ketut Arismayanti ${ }^{1,2}$ and Irma Rahyuda ${ }^{1}$ \\ ${ }^{1}$ Faculty of Tourism Udayana University, Bali, Indonesia \\ ${ }^{2}$ Center of Excellence of Tourism Udayana University, Bali, Indonesia \\ Corresponding Author: arismayanti_pariwisata@unud.ac.id
}

\section{ARTICLE INFO}

Received

28 July 2020

Accepted

31 August 2020

Available online

30 September 2020

\begin{abstract}
Post natural disaster there is a shift in the atributs selection of tourism destinations. This research was conducted at a Bali tourism destination when Agung mountain natural disaster occurred. The background of the research objective to find out the preferences of overseas tourists, in choosing tourist destinations during their visit destinations by comparing the conditions of pre and post natural disasters. The types of data used in this study are qualitative and quantitative data. Data sources come from primary and secondary data. Data collection techniques by observation, interviews, questionnaires, documentation and literature. Data analysis techniques with descriptive statistics and conjoint analysis, sampling techniques with Slovin formulas for foreign tourists who have visited Bali pre and post natural disasters of Mount Agung eruption. This research findings that preferences of foreign tourists in the selection of tourist destinations before natural disasters are strongly influenced by low prices / special offers, but after natural disasters are greatly influenced by information or promotion in articles in magazines/newspapers and films when to choose tourism destinations.
\end{abstract}

Keywords: preference, foreign tourist, natural disaster, tourism destination

\section{INTRODUCTION}

Natural disasters cannot be avoided. Wherever we are, have the opportunity to be affected by natural disasters. Likewise, tourists who visit a tourism destination, they are far from their home country, the possibility of natural disasters that they will http://ojs.unud.ac.id/index.php/eot experience could occur. Often tourists have planned their trip to a destination, but in the planned time of travel, there is a natural disaster at the destination. Of course, this is not easy for tourists and tourism managers in these destinations. The findings of this study are expected to be used as a view to see the disaster from the market point of e-ISSN: 2407-392X. p-ISSN: 2541-0857 
view, in this case tourists. Tourism management is not only seen from pleasure activities, but also pays attention and anticipates the possibility of a crisis, one of which is natural disasters.

Natural disasters are caused by hydro-meteorological, climatological, geophysical and biological phenomena which adversely impact on the natural and built environment of affected regions (Mata-Lima et al, 2013). Community participation as a host in a destination has an important role in disaster management. There is a need for dissemination of information regarding disaster response earlier in the experience of health professionals, prior to the occurrence of a disaster (Dunin-Bell, 2018). The natural disaster of the eruption of Mount Agung that occurred in Bali had a major impact on the condition of tourism on the island. Mount Agung which has an altitude of 3142 masl (meters above sea level) has a long history of eruptions. Based on PVMBG records (Center for Volcanology and Geological Disaster Mitigation), the volcano has erupted four times since 1800. Four eruptions occurred in 1808, 1821, 1843, and the last was in 1963. The last natural disaster in 1963 occurred since February 18, 1963 and ended on January 27, 1964. Natural disasters are magmatic. The eruption of the mountain in 1963 people were injured (Tempo, 2017).

Bali is a world tourist destination. Tourists who come to Bali continue to increase from year to year. Bali region is divided into eight districts and one city. Besides Bali Island, Bali also consists of other small islands, namely Nusa Penida Island, Nusa Lembongan, and Nusa Ceningan which are Klungkung Regency, Serangan Island in Denpasar City, and Menjangan Island in Buleleng Regency. Bali is geographically located at $8^{\circ} 3^{\prime} 40$ "$8^{\circ} 50 ' 48 "$ South Latitude and $114^{\circ} 25^{\prime} 53$ "-115 ${ }^{\circ} 42^{\prime} 40^{\prime \prime}$ East Longitude. Relief and topography of the island of Bali in the midst of a mountain range that extends from west to east. Bali is located between Java and Lombok. The total area of Bali as a whole reach $5,636.66 \mathrm{~km}^{2}$ or 0.29 percent of the vast Indonesian archipelago.

Based on relief and topography, in the middle of the island of Bali lies a mountain range extending from west to east and between these mountains there is a cluster of volcanoes, namely Mount Agung which is the highest point in Bali as high as 3,142 meters. This volcano last erupted on 61 March 1963. Mount Batur (1,717 meters) located in Bangli is also one of the volcanoes. While the volcanic mountains include Mount Merbuk (1,356 meters) in Jembrana, Mount Patas (1,414 meters) in Buleleng, and Mount Seraya (1,058 meters) 
in Karangasem, and several other mountains. The existence of these mountains causes the geographical area of Bali to be divided into two unequal parts, namely North Bali with a narrow and sloping lowland, and South Bali with a broad and gentle lowland. The slope of Bali Island consists of flat land (0-2 percent) covering 122,652 ha, undulating land (2-15 percent) covering 118,339 ha, steep land (15-40 percent) covering 190,486 ha and very steep land (> 40 percent) covering an area of 132,189 ha. Bali also has four lakes, namely Lake Beratan, Lake Buyan, Lake Tamblingan and Lake Batur.

\section{Research Objective}

This research was conducted in Bali for one year, since the eruption of Mount Agung and the closure of I Gusti Ngurah Rai Airport for 3 days (27-29 November 2017) which resulted in many tourists feeling anxious and returning to their country and also many tourists who canceled planned visit to Bali. Room occupancy rates dropped dramatically to levels below 10\% in December 2017. Various marketing and promotional efforts were undertaken by tourism 'stakeholders to attract tourists' interest in visiting this island of the gods. Although the current condition of Mount Agung has been lowered from alert to alert, tourist arrivals are not as much as the previous year in the same period. The visit is dominated by domestic tourists. However, the number of foreign tourists began to increase, although not significantly. This study aims to determine the preferences of foreign tourists on a trip to Bali as seen from the selection of tourist destinations visited while in Bali given the eruption of Mount Agung natural disaster has not ended and eruptions can occur at any time. In this study tourists who will be respondents are foreign tourists who have made repeated visits to Bali, that is before natural disasters and return visits after natural disasters. By conducting a comparative analysis of the preferences of visiting foreign tourists, it is hoped that this research will be able to produce a recovery policy in Bali after natural disasters.

\section{LITERATURE REVIEW}

The eruption of Mount Agung at the end of 2017 has had a significant impact on the condition of tourism in Bali. In November 2017, many tourists canceled their visit to Bali, even though December was a high season because many tourists celebrated Christmas and the New Year in Bali. Various marketing and promotional efforts continue to be carried out by the stakeholders' to restore the image of Bali as a tourist destination that is safe to visit. This e-ISSN: 2407-392X. p-ISSN: 2541-0857 
of course also affects the government's target of the number of tourists visiting Indonesia and plans for several world events to be held in Bali. The theories / concepts used in this study include:

\section{1) Preferences}

Preference is as or (the right to) take precedence and take precedence over others or it can also have the meaning of choice, tendency, liking, so preference is interpreted as a person's tendency to prioritize something (Language Center of the Ministry of National Education, 2002: 894). Meanwhile, according to Frank (2011: 63), preference is the process of ranking all things that can be consumed with the aim of obtaining a preference for a product or service. Consumer preferences appear in the alternative evaluation stage in the purchasing decision process. In that stage the consumer is faced with a wide choice of products and different kinds of different attributes.

Based on the above definition, it can be concluded that preference is a ranking process that reflects preferences or tendencies with the aim of obtaining a preference for a product or service. Kotler and Keller (2009: 229) state that there are three patterns of preference that can be formed: (1) Homogeneous preferences indicate a market where all consumers have almost the same preferences, markets do not show natural segments; (2) Diffused http://ojs.unud.ac.id/index.php/eot preferences, consumers with this preference have very varied preferences. If there are several brands in the market, each wants to position themselves in the competition space and show real differences to adjust to differences in consumer preferences; (3) Group preferences are generated when natural market segments arise from groups of consumers with the same preferences.

\section{2) Tourist Characteristics}

Talking about tourism, certainly will not be separated from people who travel or are known as tourists. Soekadijo (2000: 3) sets limits "A tourist is a person who travels from his residence without staying in the place he is visiting or only temporarily staying at the place he is visiting". According to Seaton and Bennet (in Suwena and Widyatmaja, 2010: 39) the picture of tourists is usually distinguished by the characteristics of the trip (trip descriptor) and the characteristics of the tourist (tourist descriptor).

(1) Trip Descriptor, tourists are divided into groups based on the type of trip they take. Several groupings of tourists based on their travel characteristics can be seen in Table 1 .

(2) Tourist Descriptor, focusing on tourists, is usually described as "Who wants what, why, when, where, and how much?" To explain these things, e-ISSN: 2407-392X. p-ISSN: 2541-0857 
several characteristics are used, including the following.

Table 1.

Characteristics of Tourist Travel

\begin{tabular}{ll}
\hline Characteristics & Distribution \\
\hline \multirow{3}{*}{ Length of visit } & $1-3$ days \\
& $4-7$ days \\
& $8-28$ days \\
& $29-91$ days \\
& $92-365$ days \\
\hline Distance traveled (can & Local \\
be used kilometers / & In one province \\
miles) & Other province \\
& Overseas \\
\hline Time to travel & Daily time \\
& Weekend \\
& Holiday \\
& Break school \\
\hline Accommodation used & Comercial (star \\
& and non-star hotel) \\
& Non comercial \\
& (stay in \\
& friend/family \\
& house) \\
\hline Travel organization & Flight \\
& Car \\
& Train \\
& Cruise \\
\hline Modes of & By self \\
transportation & Trampaly \\
& \\
\hline & \\
& Travel agent \\
& \\
& \\
&
\end{tabular}

Source: Smith (1989) in Suwena and Widyatmaja (2010).

\section{Socio-Demographic Characteristics}

Socio-Demographic Characteristics try to answer the question "who wants what". This division based on these characteristics is most often done in the interests of tourism analysis, planning, and marketing, because the definition is very clear and the distribution is relatively easy (Kotler, 1996). Some further classifications of socio-demographic characteristics can be seen in Table 2.

Table 2.

Socio-Demographic Characteristics of Tourists

\begin{tabular}{cl}
\hline Characteristics & \multicolumn{1}{c}{ Distribution } \\
\hline \multirow{2}{*}{ Gender } & Man \\
& Women \\
\hline \multirow{3}{*}{ Ages } & $0-14$ year old \\
& $15-24$ \\
& $25-44$ \\
& $45-64$ \\
& $>65$ \\
\hline & Not completed in \\
& primary school \\
& Elementary school \\
& High school \\
& Diploma \\
& Bachelor degree) \\
& Post Graduate (S2, S3) \\
& Work (civil servants / \\
Education level & employees, \\
& entrepreneurs, \\
& professionals and others) \\
& Not working \\
& (housewives, students) \\
\hline & Single \\
Marital status & Maried \\
& Divorse \\
\hline &
\end{tabular}

Source: Smith (1989) in Suwena dan Widyatmaja (2010).

Geographical Characteristics

Geographical characteristics divide tourists based on their location of residence, usually divided into village-city, province, or country of origin. This division can also be further grouped based on the size (size) 
of the city of residence (small, medium, large / metropolitan), population density in the city and others.

\section{Psychographic Characteristics}

These psychographic characteristics divide tourists into groups based on social class, life style and personal characteristics. Tourists in the same demographic group may have very different psychographic profiles.

Wall and Mathieson (2006) states that tourist profiles can be divided into 2 , namely: 1) Characteristics of tourists viewed from the socioeconomic (age, level of education, income, employment, family size, family life cycle, experiences that affect attitudes, perceptions, motivation and decisions taken); 2) Characteristics of tourists as seen from their behavior which includes the needs, desires, motivations consisting of driving factors and pull factors in carrying out tourism activities, the attitude of travel features and attributes of the chosen destination, awareness and sources of information in traveling. In addition, in a cognitive-normative approach, Plog (in Pitana and Diarta, 2009: 48) develops the typology of tourists as follows:

(1) Allocentric, namely tourists who want to visit places that are not yet known, are adventure (adventure), and utilize the facilities provided by the local community.

(2) Phychocentric, namely tourists who only want to visit tourist destinations that already have facilities with the same standards as those in their own country. They travel with certain programs and utilize facilities with international standards.

(3) Mid-centric, located between allocentric and phycocentric.

Based on tourist behavior in a tourist destination, Gray (1970) in Pitana and Diarta (2009: 49) distinguishes tourists into two, namely: (1) sunlust and (2) wanderlust. Sunlust tourist is a tourist who visits an area with the main purpose for rest or relaxation. This type of tourist expects climate conditions, facilities, food, etc. that are in accordance with the standards in their home country. In contrast, wanderlust tourists are tourists whose travel trips are driven by motivation to gain new experiences, learn new cultures, or admire natural beauty that has never been seen. Tourists like this are more interested in tourist destinations that are able to offer cultural uniqueness or natural scenery that has high learning value.

\section{3) Tourism Destination}

Law Number 10 of 2009 concerning Tourism states that a tourism destination is a geographical area within one or more e-ISSN: 2407-392X. p-ISSN: 2541-0857 
administrative regions in which there are tourist attractions, public facilities, tourism facilities, accessibility, and communities that are interrelated and complement the realization of tourism. Whereas Pitana and Diarta (2009) define a tourism destination as a place that is visited with a significant period of time during one's trip when compared to other places traversed during the trip. In addition, Hadinoto (1996) states that a tourist destination is a specific area chosen by a visitor, where he can stay and reside for a certain period of time. Based on a review of tourism destinations it can be concluded that a tourism destination is a geographical area visited by a visitor in which there is a tourist attraction, public facilities, tourism facilities, accessibility, as well as communities that are interrelated and complement the realization of tourism. Manolis (2011) in the TRAVELSAT benchmaking survey states that the main factors influencing tourists in choosing tourist destinations are as follows: 1) Friends or relatives recommendation; 2) World renowned must-see destination; 3) Information on the web; 4) Cheap deal/ special offer; 5) Geographically close destination; 6) Travel agency recommendation; 7) Article in a magazine/ newspaper; 8) Movie realized in the country; 9) Appealing advertising on it; and 10) Heard about in the TV news.

\section{METHODOLOGY}

This research is a collaboration between qualitative and quantitative approaches conducted by observation, interviews, and questionnaires. Presentation of the results of data analysis is done formally (in table form) or informal (in narrative form). The study began with the distribution of questionnaires related to the preferences of foreign tourists in choosing tourist destinations in Bali before and after the eruption of Mount Agung. The variables used in this study related to the preferences of foreign tourists towards tourist destinations are (Manolis, 2011): 1) Friends or relatives recommendation; 2) World renowned must-see destination; 3) Information on the web; 4) Cheap deal/ special offer; 5) Geographically close destination; 6) Travel agency recommendation; 7) Article in a magazine/ newspaper; 8) Movie realized in the country; 9) Appealing advertising on it; and 10) Heard about in the TV news.

While the data sources are primary data and secondary data. Determination of respondents in this study using Accidental Sampling techniques. The number of respondents taken using the Slovin Formula, with an error rate of $10 \%$ specifically for foreign tourists as many as 100 people. Foreign tourists selected as respondents are foreign tourists who have e-ISSN: 2407-392X. p-ISSN: 2541-0857 
made repeated visits to Bali, that is before natural disasters and return visits after the eruption of Mount Agung, so based on tourist preferences it can be seen whether there are differences in the selection of tourist destinations in Bali. Bali related to natural disasters. By conducting a comparative analysis of the preferences of visiting foreign tourists, it is hoped that this research will be able to produce a recovery policy for Bali tourism after natural disasters. In this study used descriptive statistical analysis techniques and conjoint analysis.

Descriptive statistics are used to analyze data by describing or describing data that has been collected as it is without intending to make conclusions that apply to the public or generalize. Conjoint Analysis is an analysis technique used to examine the impact of the attributes of an object or service simultaneously on a person's preferences for that object or service (Gudono, 2015).

\section{RESULTS AND DISCUSSION}

\section{Characteristics of Tourists Visiting Bali}

Data of foreign tourists visiting Bali every year shows an increasing trend, but interestingly there is a change in the trend of visits by nationality. If in previous years Australian national tourists who dominated the visit to Bali, but in 2017 and 2018 were http://ojs.unud.ac.id/index.php/eot dominated by Chinese tourists. Likewise, the number of Indian tourists visiting Bali showed an upward trend and was ranked third after Australia. The number of Chinese tourists who come to Bali is generally in groups and uses the services of a travel agent.

Based on interviews with Chinese tourists, they stated that the recommendations of families and people who were figures / idols greatly influenced their decision to visit and choose tourist destinations. For example, if there are artists that they idolize on holiday to Bali, then the tendency of fans of these artists will come to visit the tourist destination. However, the main obstacle is the ability of Chinese tourists to English, so they need a special Mandarin guide to be able to explain the tourist attractions they visit. In contrast to India, the surge in Indian tourists coming to Bali due to the opening of direct flight access from India to Bali has led to a significant increase in the number of Indian tourists visiting Bali. The number of foreign tourists visiting Bali can be seen in Tables 3 and 4. 
Table 3.

Number of Foreign Tourists Visiting Bali in 2008-2018

\begin{tabular}{ccc}
\hline Year & The number of tourist visits & Growth $(\boldsymbol{\%})$ \\
\hline 2008 & $1,968,892$ & 18.26 \\
\hline 2009 & $2,229,945$ & 13.26 \\
\hline 2010 & $2,493,058$ & 11.80 \\
\hline 2011 & $2,756,579$ & 10.57 \\
\hline 2012 & $2,892,019$ & 4.91 \\
\hline 2013 & $3,278,598$ & 13.37 \\
\hline 2014 & $3,766,638$ & 14,89 \\
\hline 2015 & $4,001,835$ & 6.24 \\
\hline 2016 & $4,927,937$ & 23.14 \\
\hline 2017 & $5,697,739$ & 15.62 \\
\hline 2018 & $6,070,473$ & 6.54 \\
\hline
\end{tabular}

Source: Dinas Pariwisata Provinsi Bali, 2018.

Table 4.

Number of Foreign Tourists Visiting Bali Based on the 20 Largest Nationalities

\begin{tabular}{cccccccc}
\hline Nationalities & $\mathbf{R}$ & $\mathbf{2 0 1 7}$ & Share (\%) & $\mathbf{R}$ & $\mathbf{2 0 1 8}$ & $+\mathbf{+ - ( \% )}$ & Share (\%) \\
\hline Chinnese & 1 & 1.385 .850 & 24,32 & 1 & 1.361 .512 & $-1,76$ & 22,43 \\
\hline Australian & 2 & 1.094 .974 & 19,22 & 2 & 1.169 .215 & 6,78 & 19,26 \\
\hline Indian & 3 & 272.761 & 4,79 & 3 & 353.894 & 29,75 & 5,83 \\
\hline British & 5 & 243.827 & 4,28 & 4 & 270.789 & 11,06 & 4,46 \\
\hline Japanese & 4 & 252.998 & 4,44 & 5 & 261.666 & 3,43 & 4,31 \\
\hline American & 6 & 191.106 & 3,35 & 6 & 236.578 & 23,79 & 3,90 \\
\hline French & 7 & 177.864 & 3,12 & 7 & 195.734 & 10,05 & 3,22 \\
\hline Malaysian & 10 & 170.459 & 2,99 & 8 & 194.760 & 14,26 & 3,21 \\
\hline German & 8 & 177.184 & 3,11 & 9 & 185.863 & 4,90 & 3,06 \\
\hline Singaporean & 12 & 125.934 & 2,21 & 10 & 144.549 & 14,78 & 2,38 \\
\hline South Korean & 9 & 174.842 & 3,07 & 11 & 143.581 & $-17,88$ & 2,37 \\
\hline New Zealand & 15 & 86.463 & 1,52 & 12 & 111.967 & 29,50 & 1,84 \\
\hline Russian & 14 & 94.898 & 1,67 & 13 & 111.610 & 17,61 & 1,84 \\
\hline Netherland & 13 & 102.235 & 1,79 & 14 & 108.429 & 6,06 & 1,79 \\
\hline Taiwanese & 11 & 129.921 & 2,28 & 15 & 106.058 & $-18,37$ & 1,75 \\
\hline Philipine & 17 & 57.826 & 1,01 & 16 & 88.344 & 52,78 & 1,46 \\
\hline Canadian & 16 & 63.385 & 1,11 & 17 & 66.619 & 5,10 & 1,10 \\
\hline Italian & 18 & 50.045 & 0,88 & 18 & 56.222 & 12,34 & 0,93 \\
\hline Spain & 19 & 44.690 & 0,78 & 19 & 51.278 & 14,74 & 0,84 \\
\hline Thailand & 20 & 42.070 & 0,74 & 20 & 47.367 & 12,59 & 0,78 \\
\hline Total & 4.939 .332 & 86,69 & & 5.266 .035 & 6,61 & 86,75 \\
\hline Others & 758.407 & 13,31 & & 804.438 & 6,07 & 13,25 \\
nationalities & & & & & & & \\
\hline Total arrival & 5.697 .739 & 100,00 & & 6.070 .473 & 6,54 & 100,00 \\
\hline So & & & & & &
\end{tabular}

Source: Dinas Pariwisata Provinsi Bali, 2018. 
The characteristics of tourists visiting Bali are seen based on gender, age, level of education, occupation, nationality, type of accommodation chosen, destination of travel, marital status, number of visits, length of visit, tourist activities undertaken and tourist attractions visited. The characteristics of tourists can be seen in Table 5.

Table 5.

Characteristics of Tourists Visiting

\begin{tabular}{|c|c|c|c|c|}
\hline No. & Variable & Indicators & Number of visits (person) & Percentage $(\%)$ \\
\hline \multirow[t]{2}{*}{1} & \multirow[t]{2}{*}{ Gender } & Man & 77 & 77 \\
\hline & & Woman & 23 & 23 \\
\hline \multirow[t]{4}{*}{2} & \multirow[t]{4}{*}{ Ages } & $15-24$ years old & 49 & 49 \\
\hline & & $25-44$ & 43 & 43 \\
\hline & & $45-64$ & 7 & 7 \\
\hline & & $>65$ & 1 & 1 \\
\hline \multirow[t]{4}{*}{3} & \multirow[t]{4}{*}{ Education level } & Junior high school & 3 & 3 \\
\hline & & Hihg school & 37 & 37 \\
\hline & & Diploma/Bachelor & 54 & 54 \\
\hline & & Master/doctoral & 6 & 6 \\
\hline \multirow[t]{5}{*}{4} & \multirow[t]{5}{*}{ Job } & Student/college & 45 & 45 \\
\hline & & Public Servant & 19 & 19 \\
\hline & & Bussiness man & 21 & 21 \\
\hline & & Private employee & 13 & 13 \\
\hline & & No work & 2 & 2 \\
\hline \multirow[t]{5}{*}{5} & \multirow[t]{5}{*}{ Nationality } & European & 41 & 41 \\
\hline & & Australian & 29 & 29 \\
\hline & & Asian & 16 & 16 \\
\hline & & American & 11 & 11 \\
\hline & & African & 3 & 3 \\
\hline \multirow[t]{5}{*}{6} & \multirow[t]{5}{*}{ Accomodation type } & Hotel & 50 & 50 \\
\hline & & Villa & 24 & 24 \\
\hline & & Homestay & 11 & 11 \\
\hline & & Cottage & 9 & 9 \\
\hline & & Bungalow & 6 & 6 \\
\hline \multirow[t]{2}{*}{7} & \multirow[t]{2}{*}{ Travel purpose } & Traveling & 87 & 87 \\
\hline & & Bussiness/MICE & 13 & 13 \\
\hline \multirow[t]{3}{*}{8} & \multirow[t]{3}{*}{ Marital status } & Single & 75 & 75 \\
\hline & & Married & 15 & 15 \\
\hline & & Divorce & 10 & 10 \\
\hline
\end{tabular}




\begin{tabular}{|c|c|c|c|c|}
\hline \multirow[t]{7}{*}{9} & \multirow[t]{7}{*}{ Travel time to Bali } & 2 times & 67 & 67 \\
\hline & & 3 times & 23 & 23 \\
\hline & & 4 times & 6 & 6 \\
\hline & & 5 times & 1 & 1 \\
\hline & & 8 times & 1 & 1 \\
\hline & & 10 times & 1 & 1 \\
\hline & & 20 times & 1 & 1 \\
\hline \multirow[t]{2}{*}{10} & \multirow[t]{2}{*}{ Use travel agency } & No & 79 & 79 \\
\hline & & Yes & 21 & 21 \\
\hline \multirow[t]{10}{*}{11} & \multirow[t]{10}{*}{ Length of stay } & 2 days & 1 & 1 \\
\hline & & 3 days & 18 & 18 \\
\hline & & 4 days & 19 & 19 \\
\hline & & 5 days & 1 & 1 \\
\hline & & 1 week & 34 & 34 \\
\hline & & 2 weeks & 9 & 9 \\
\hline & & 3 weeks & 1 & 1 \\
\hline & & 1 month & 13 & 13 \\
\hline & & 2 months & 3 & 3 \\
\hline & & 5 months & 1 & 1 \\
\hline \multirow[t]{11}{*}{12} & \multirow{11}{*}{$\begin{array}{l}\text { The tourist attraction } \\
\text { visited }\end{array}$} & Kuta beach & 69 & NA \\
\hline & & Sanur & 18 & NA \\
\hline & & Ubud & 18 & NA \\
\hline & & Seminyak & 16 & NA \\
\hline & & Legian & 14 & NA \\
\hline & & Canggu & 9 & NA \\
\hline & & Nusa Dua & 8 & NA \\
\hline & & Monkey Forest & 8 & NA \\
\hline & & $\begin{array}{l}\text { Padang-Padang } \\
\text { beach }\end{array}$ & 7 & NA \\
\hline & & Tanah Lot & 6 & NA \\
\hline & & Others & 24 & NA \\
\hline \multirow[t]{8}{*}{13} & \multirow{8}{*}{$\begin{array}{l}\text { The tourist activities } \\
\text { carried out }\end{array}$} & Culinary & 69 & NA \\
\hline & & Swimming & 39 & NA \\
\hline & & Surfing & 23 & NA \\
\hline & & Shopping & 13 & NA \\
\hline & & Walking around & 11 & NA \\
\hline & & Diving & 9 & NA \\
\hline & & Praying & 5 & NA \\
\hline & & Others & 11 & NA \\
\hline
\end{tabular}

Source: data of reseach, 2018. 
The characteristics of tourists are dominated by men, the age range of adolescents and young adults with a Diploma / Strata education level 1. The characteristics of tourists based on nationality can be seen that European nationality tourists dominate (41 percent), and then followed by Australian, Asian and American tourists.

Characteristics of tourists based on marital status, dominated by unmarried, the number of visits 2 times, do not use the services of a travel agent, the most time per visit per visit for 1 week and the most tourist attraction chosen by tourists as a tourist spot is Kuta Beach. Tourism activities carried out while in Bali, it can be seen that the most tourist activities undertaken by tourists are culinary tours, then followed by swimming, surfing, shopping, walking, diving, and praying activities. Other activities include: SPA and massage, watching the sun, sunbathing, climbing, yoga, jogging, paraselling, business, watching Barong Dance, and visiting family.

\section{Preferences of Foreign Tourists Pre and Post Natural Disasters of Mount Agung Eruption}

Based on the results of the Conjoin analysis in this study which is divided into four parts, namely the implementation of the pre-test, the results of the Conjoin http://ojs.unud.ac.id/index.php/eot analysis, the utility level analysis of each attribute, and the analysis of the importance level of the attribute. The level of importance attribute the recommendation of friends / relatives, the value of the utility is not recommended friends / relatives shows a positive number 0.561 for foreign tourists before natural disasters and a positive number 0.922 for foreign tourists after natural disasters. While the recommendation of friends / relatives only get a utility value that shows a negative number of 0.561 for foreign tourists before natural disasters and a negative number of 0.922 for foreign tourists after natural disasters. This shows that before and after the eruption of Mount Agung, foreign tourists did not prefer the recommendation of friends / relatives in choosing a tourist destination.

In the attribute of destination that must be seen by the world, the value of utility not destination that must be seen shows a positive number of 0.352 for foreign tourists before natural disasters and a positive number of 0.500 for foreign tourists after natural disasters. Whereas the attribute of destination that must be seen gets a utility value which shows a negative number of 0.352 for foreign tourists before natural disasters and a negative number of 0.500 for foreign tourists after natural disasters. It can be concluded that before and after the eruption of Mount Agung, e-ISSN: 2407-392X. p-ISSN: 2541-0857 
foreign tourists prefer tourist destinations not based on world renowned must-see destination.

Attribute information on the website, the value of utilities no information on the website shows a positive number of 0.806 for foreign tourists before natural disasters and a positive number of 0.895 for foreign tourists after natural disasters. Whereas information on the website about tourist destinations received utility values which showed a negative number of 0.806 for foreign tourists before natural disasters and a negative number of 0.895 for foreign tourists after natural disasters. It can be concluded that before and after the eruption of Mount Agung, foreign tourists prefer there is no information on the website about tourist destinations.

Low price attributes / special offers, foreign tourists prefer low prices or special offers before natural disasters with a positive utility value of 0.297 . Whereas after natural disasters, foreign tourists tend not to choose low prices / special offers with a positive utility value of 0.640 . The value of low-cost utility / special offers shows a positive number of 0.297 for foreign tourists before natural disasters and a negative number of 0.640 for foreign tourists after natural disasters. While not a cheap price/special offer on tourist destinations, the utility value shows a http://ojs.unud.ac.id/index.php/eot negative number of 0.297 for foreign tourists before natural disasters and a positive number of 0.640 for foreign tourists after natural disasters. It can be concluded that there is a difference in the orientation of the election between before and after the natural disaster of the eruption of Mount Agung based on low prices/special offers.

In terms of location proximity, foreign tourists prefer proximity to locations with a positive utility value of 0.016 before natural disasters. Meanwhile, after a natural disaster, foreign tourists do not choose the proximity of the location with a positive utility value of 0.468 . The value of the proximity location utility shows a positive number of 0.016 for foreign tourists before natural disasters and a negative number of 0.468 for foreign tourists after natural disasters. While not the proximity of the location in the selection of tourist destinations get a utility value that shows a negative number of 0.016 for foreign tourists before natural disasters and a positive number of 0.468 for foreign tourists after natural disasters. It can be concluded that there was a difference in the orientation of the election between before and after the natural disaster of the eruption of Mount Agung based on the proximity of the location. 
The attribute of a travel agent recommendation, the value of the utility not recommended by the travel agent shows a positive number of 0.581 for foreign tourists before natural disasters and a positive number of 0.730 for foreign tourists after natural disasters. While recommendations from travel agents get utility values that show a negative number of 0.581 for foreign tourists before natural disasters and a negative number of 0.730 for foreign tourists after natural disasters. It can be concluded that before and after the eruption of Mount Agung, foreign tourists are more likely not to choose a recommendation from a travel agent.

Article attributes in magazines / newspapers, foreign tourists prefer articles in magazines in the selection of tourist destinations before and after natural disasters compared to articles in newspapers. The utility value of articles in the magazine shows a positive number of 0.744 for foreign tourists before natural disasters and a positive number of 0.830 for foreign tourists after natural disasters. While articles in the newspaper get a utility value that shows a negative number of 0.744 for foreign tourists before natural disasters and a negative number of 0.830 for foreign tourists after natural disasters. It can be concluded that before and after the eruption of Mount Agung, foreign tourists chose articles in the magazine as a medium http://ojs.unud.ac.id/index.php/eot in the selection of tourist destinations. In the film attribute, the value of destination utilities contained in a film shows a positive number of 0.353 for foreign tourists before natural disasters and a positive number of 0.447 for foreign tourists after natural disasters. Whereas the destination not in any film gets a utility value which shows a negative number of 0.353 for foreign tourists before natural disasters and a negative number of 0.447 for foreign tourists after natural disasters. It can be concluded that before and after the eruption of Mount Agung, the film media affected the selection of tourists in choosing tourist destinations.

Attractive advertising attributes, foreign tourists do not choose tourist destinations based on attractive advertisements, both before and after natural disasters. The utility value of not choosing based on attractive advertisements shows a positive number of 0.644 for foreign tourists before natural disasters and a positive number of 0.607 for foreign tourists after natural disasters. Whereas choosing tourist destinations based on attractive advertisements gets utility values that show a negative number of 0.644 for foreign tourists before natural disasters and a negative number of 0.607 for foreign tourists after natural disasters. It can be concluded that before and after the eruption of Mount Agung, foreign tourists 
did not choose a tourist destination based on attractive advertisements. Attributes hear the news on TV, the value of utilities not hearing about tourist destinations on TV news shows a positive number of 0.544 for foreign tourists before natural disasters and a positive number of 0.813 for foreign tourists after the disaster. While hearing about tourist destinations on TV news has a utility value which shows a negative number of 0.544 for foreign tourists before natural disasters and a negative number of 0.813 for foreign tourists after natural disasters. It can be concluded that before and after the eruption of Mount Agung, foreign tourists prefer tourist destinations not based on information from TV news.

\section{Attribute Importance Analysis}

Analysis of the importance of attributes will produce the attributes that are most considered by tourists in choosing tourist destinations, both before and after natural disasters. The results of questionnaire data processing with conjoint analysis showed the importance level of attributes sorted from the most important to the least important attributes. The level of importance of attributes can be seen in Table 6.

\begin{tabular}{lcc}
\hline \multicolumn{1}{c}{ Indicators } & $\begin{array}{c}\text { Pre the } \\
\text { Mount } \\
\text { Agung } \\
\text { Natural } \\
\text { Disasters }\end{array}$ & $\begin{array}{c}\text { Post the } \\
\text { Mount } \\
\text { Agung } \\
\text { Natural } \\
\text { Disasters }\end{array}$ \\
\hline $\begin{array}{l}\text { Friends or relatives } \\
\text { recommendation }\end{array}$ & 8.351 & 10.764 \\
\hline $\begin{array}{l}\text { World renowned must- } \\
\text { see dest }\end{array}$ & 10.752 & 9.461 \\
\hline $\begin{array}{l}\text { Information on the } \\
\text { website }\end{array}$ & 9.470 & 10.220 \\
\hline $\begin{array}{l}\text { Cheap deal/ special } \\
\text { offer }\end{array}$ & 11.472 & 8.889 \\
\hline $\begin{array}{l}\text { Geographically close } \\
\text { destination }\end{array}$ & 12.549 & 9.120 \\
\hline $\begin{array}{l}\text { Travel agency } \\
\text { recommendation }\end{array}$ & 9.823 & 10.898 \\
\hline $\begin{array}{l}\text { Article in a magazine/ } \\
\text { newspaper }\end{array}$ & 11.359 & 13.296 \\
\hline $\begin{array}{l}\text { Movie realized in the } \\
\text { lountry }\end{array}$ & 9.288 & 10.074 \\
\hline $\begin{array}{l}\text { Appealing advertising } \\
\text { on it }\end{array}$ & 7.899 & 7.242 \\
\hline $\begin{array}{l}\text { Heard about in the TV } \\
\text { news }\end{array}$ & 9.038 & 10.035 \\
\hline \multicolumn{1}{c}{ TOTAL } & 99.99 & 99.99 \\
\hline $\begin{array}{l}\text { Solrce } \\
\text { The }\end{array}$ & & \\
\hline
\end{tabular}

Source: data of research, 2018.

Table 7 shows that the most important attribute according to respondents in choosing tourist destinations in Bali prior to natural disasters was the proximity attribute of location with a percentage of 12.549 percent. Furthermore, the second factor that is considered by foreign tourists is the attribute of low prices or special offers with a percentage of 11.472 percent. The third attribute is the attribute of articles in magazines/ newspapers with a percentage of 11.359 percent. Unlike the consideration of foreign tourists after a natural disaster with the e-ISSN: 2407-392X. p-ISSN: 2541-0857 
attribute value of articles in magazines / newspapers (13.296 percent), travel agent recommendations (10.898 percent), recommendations of friends / relatives (10.764 percent). The order of importance based on the attributes most considered by tourists in choosing tourist destinations, both before and after the natural disaster of the eruption of Mount Agung can be seen in Table 7.

Table 7. Sequence of Attributes Based on Level of Interest

\begin{tabular}{|c|c|c|}
\hline Rank & $\begin{array}{l}\text { Pre the Natural } \\
\text { Disasters }\end{array}$ & $\begin{array}{l}\text { Post the Natural } \\
\text { Disasters }\end{array}$ \\
\hline 1 & $\begin{array}{l}\text { Geographically } \\
\text { close destination }\end{array}$ & $\begin{array}{l}\text { Article in a } \\
\text { magazine/ } \\
\text { newspaper }\end{array}$ \\
\hline 2 & $\begin{array}{l}\text { Cheap deal/ } \\
\text { special offer } \\
\text { spesial }\end{array}$ & $\begin{array}{l}\text { Travel agency } \\
\text { recommendation }\end{array}$ \\
\hline 3 & $\begin{array}{l}\text { Article in a } \\
\text { magazine/ } \\
\text { newspaper }\end{array}$ & $\begin{array}{l}\text { Friends or } \\
\text { relatives } \\
\text { recommendation }\end{array}$ \\
\hline 4 & $\begin{array}{l}\text { World renowned } \\
\text { must-see } \\
\text { destination }\end{array}$ & $\begin{array}{l}\text { Information on } \\
\text { the website }\end{array}$ \\
\hline 5 & $\begin{array}{l}\text { Travel agency } \\
\text { recommendation }\end{array}$ & $\begin{array}{l}\text { Heard about in } \\
\text { the TV news }\end{array}$ \\
\hline 6 & $\begin{array}{l}\text { Information on } \\
\text { the website }\end{array}$ & $\begin{array}{l}\text { Movie realized in } \\
\text { the country }\end{array}$ \\
\hline 7 & $\begin{array}{l}\text { Movie realized } \\
\text { in the country }\end{array}$ & $\begin{array}{l}\text { World renowned } \\
\text { must-see } \\
\text { destination }\end{array}$ \\
\hline 8 & $\begin{array}{l}\text { Heard about in } \\
\text { the TV news }\end{array}$ & $\begin{array}{l}\text { Geographically } \\
\text { close destination }\end{array}$ \\
\hline 9 & $\begin{array}{l}\text { Friends or } \\
\text { relatives } \\
\text { recommendation }\end{array}$ & $\begin{array}{l}\text { Cheap deal/ } \\
\text { special offer }\end{array}$ \\
\hline 10 & $\begin{array}{l}\text { Appealing } \\
\text { advertising on it }\end{array}$ & $\begin{array}{l}\text { Appealing } \\
\text { advertising on it }\end{array}$ \\
\hline
\end{tabular}

Source: data of research, 2018.

\section{Significance and Predictive Accuracy Testing}

Significance and predictive accuracy testing in this study was conducted on 100 respondents. Significance testing in research using conjoint analysis can be done by looking at the value of Pearson's R and Kendall's Tau correlations based on questionnaire data processing. Pearson's R and Kendall's Tau significance values if under 0.05 , then have a very strong significance relationship.

The results of the Conjoint analysis will be validated by looking at Pearson's $\mathrm{R}$ and Kendall's Tau Correlation values, if the correlation value shows a number above 0.5 , it can be interpreted that the correlation has a strong predictive accuracy or otherwise valid. The results of the questionnaire data that have been processed using Statistical Package for the Social Sciences (SPSS) version 18, have a correlation value that can be seen in Table 8.

Table 8. Correlation Value between Attributes

\begin{tabular}{lllll}
\hline & $\begin{array}{c}\text { Utilities Pre } \\
\text { Natural disaster }\end{array}$ & \multicolumn{2}{c}{$\begin{array}{c}\text { Utilities Post } \\
\text { Natural disaster }\end{array}$} \\
\cline { 2 - 5 } & Value & Sig & Value & Sig \\
\hline Pearson's $\boldsymbol{R}$ & 0,994 & 0,000 & 0,996 & 0,000 \\
\hline $\begin{array}{l}\text { Kendall's } \\
\text { tau }\end{array}$ & 0,939 & 0,000 & 1,000 & 0,000 \\
\hline
\end{tabular}

Source: data of research, 2018. 
Based on Table 8 it can be seen that the significance value of Pearson's $\mathrm{R}$ and Kendall's Tau is 0.00 (below 0.05) which means that each attribute has a very strong significance relationship. While the Pearson's R correlation value of 0.980 and Kendall's Tau of 0.875 means that the value is above 0.5, thus indicating a strong relationship between estimate and actual. Thus, it can be said that the opinions of the 100 respondents can be accepted to describe the preferences of tourists towards the selection of tourist destinations before and after the natural disaster of Mount Agung.

\section{Bali Tourism Post-Natural Disaster Recovery Policy}

Based on the results that have been described above can be given several considerations related to the recovery policy of tourism in Bali after natural disasters, among others:

(1) The existence of Mount Agung natural disasters, information in print and electronic media and information from travel agents becomes very important and basis for tourists to decide in choosing a tourist destination when traveling. The information presented will form public opinion which will later spread by word of mouth which will be a recommendation from friends / relatives who are important attributes in the selection of tourist destinations. The media should be careful in providing information because it can form opinions and images about the condition of tourism destinations. The role of the media in providing true and positive information greatly helps the speed of recovery of a tourist destination affected by disaster.

(2) When natural disasters occur, various promotional and marketing activities in the form of advertisements, various low price offers are not able to influence tourists' decisions in choosing tourist destinations. So various hot deal offers and other promotions are not recommended.

(3) Films have a large impact in shaping information, images and ideas for visiting and choosing these tourist destinations. Lots of tourist destinations then become famous after being used as the background of a film. Promotion through film is highly recommended, of course the theme in the film should be able to strengthen the brand image of the tourist destination which is used as the location of shooting the film, provide a positive image / image and have a positive impact on tourist destinations. 
The importance of creating tourist loyalty because the cost required is less than the cost of promotion and marketing in attracting new tourists. Tourist loyalty will only be created if tourists are satisfied with existing tourist products. More tourism products are services or combinations of services and goods. Providing the best possible service to tourists supported by all tourism stakeholders in Bali will be able to realize tourist loyalty.

\section{CONCLUSION}

Preferences of foreign tourists in the selection of tourist destinations before natural disasters are greatly influenced by low prices/special offers, proximity of locations, articles in magazines/ newspapers and films. The order of attributes based on the level of interest of foreign tourists in the selection of destinations before natural disasters is the proximity of the location, low prices/ special offers, articles in magazines/ newspapers, destinations that must be seen in the world, travel agent recommendations, information on websites, films, hear about on the news TV, recommendations of friends/relatives, and interesting advertisements.

Preferences of foreign tourists in the selection of tourist destinations after natural disasters are greatly influenced by articles http://ojs.unud.ac.id/index.php/eot in magazines / newspapers and films. The order of attributes based on the level of interest of foreign tourists in the selection of destinations after natural disasters is an article in a magazine / newspaper, travel agent recommendations, recommendations of friends / relatives, information on the website, hear about on TV news, films, destinations to be seen in the world, proximity of locations, cheap prices / special offers, attractive advertisements. Bali tourism recovery policy after natural disasters is the importance of information conveyed media as well as information from travel agents as a basis for tourists to decide in choosing a tourist destination when traveling.

The role of the media in providing positive information greatly helps the speed of recovery of a disaster-affected tourist destination. In addition, film has a large impact in shaping information, images and ideas for visiting and choosing tourist destinations and being able to strengthen the brand image of a tourist destination that is used as the location of shooting films, providing a positive image / image and having a positive impact on tourist destinations.

The suggestions that can be conveyed in this study are based on the objectives of the problem and suggestions from tourists when the questionnaire is distributed, including: 
(1) The natural disaster of Mount Agung is very well understood by tourists who come as something that cannot be predicted, but the most important thing is the readiness of Bali tourism stakeholders in the destination in providing precise and accurate information and being able to provide certainty, guarantee safety and professional in handling when the disaster occurs.

(2) The emergence of various hoaxes and various information deliberately exaggerated for a long time on various information media and social media can destroy the image of a destination. Various post-disaster promotion and recovery efforts carried out after the disaster so far have only been in vain. The government should make regulations that can act on this. If Bali and Indonesia are committed to developing tourism, all stakeholders should have an obligation to protect it.

(3) Increasing the number and capacity development of the existing Tourism Information Center.

(4) The importance of improving services to tourists in various economic sectors and activities.
The importance of maintaining environmental cleanliness and free of plastic waste. If we are able to do it, Bali's image as a tourist destination will be better.

\section{REFERENCES}

Alano, Emmanuel and Minsoo Lee 2016, Natural Disaster Shocks and Macroeconomic Growth in Asia: Evidence for Typhoons and Droughts, 2016 Asian Development Bank 6 ADB Avenue, Mandaluyong City, 1550 Metro Manila, Philippines, ISSN 2313-6537 (Print), 2313-6545 (e-ISSN) Publication Stock No. WPS168584-2.

Alma, Buchari 2007, Manajemen Pemasaran dan Pemasaran Jasa, Alfabeta, Bandung.

Anonim 2008, Kamus Besar Bahasa Indonesia, Gramedia Pustaka Utama, Jakarta.

Anonim 2009, Undang-Undang RI Nomor 10 tahun 2009 tentang Kepariwisataan.

Barsky, Jonathan 2012, Points, Price, Promotions? How Guests Select Hotels Around the World. Available: http//hotelexecutive.com/business_re view/3381/points-price-promotionshow-guests-select-hotels-around-theworld

Badan Pusat Statistik (BPS) Provinsi Bali, 2018. Bali dalam Angka 2017, Badan Pusat Statistik Provinsi Bali.

Bordelon, Bridget M, Ksenia Kirillova, and Jeffrey Schaffer 2015, Tourism Planning Post Disaster: Community Perceptions of Tourism Development, Department of Hotel Management, BIT-Mesra, Ranchi-835215, JOHAR - Journal of Hospitality Application $\&$ Research Volume 10 Issue 2 June 2015 .

http://ojs.unud.ac.id/index.php/eot 
Cooper, Chris and Stephen Jackson 1997, Destination Life Cycle: The Isle of Man Case Study. Dalam the Earthscan Reader in Sustainable Tourism, Earthscan Publications Limited, United Kingdom.

Cooper, Chris, Jhon Flecher, David Gilbert and Stephen Wainhill 1993, Tourism Principle and Practice, Pitman Publishing, London.

Disparda Bali 2017, Statistik Daerah Provinsi Bali. Available: http://www.disparda.baliprov.go.id/

Doorley, John and Helio Fred Garcia 2010, Reputation Management: The Key to Successful Public Relations and Corporate Communication, Routledge Taylor \& Francis Group, New York.

Dunin-Bell, Ola 2018, What do They Know? Guidelines and Knowledge Translation for Foreign Health Sector Workers Following Natural Disasters, Prehospital and Disaster Medicine Vol. 33, No. 2.

Erdeli, George, Aurel Gheorghilaş, and Corina Gheorghilaş 2015, the Importance of Geographical Hazards Analysis for The Development of Tourist Facilities in Mountain Areas, "Dimitrie Cantemir" Christian University Knowledge Horizons Economics Volume 7, No. 3, pp. 130-133 P-ISSN: 2069-0932, EISSN: 2066-1061 C 2015 Pro Universitaria www.orizonturi.ucdc.ro.

Frank, Robert H 2011, Microeconomics and Behaviour Eighth edition, Mc. Graw Hill International Edition.

Gudono 2015, Analisis Data Multivariat, BPFE, Yogyakarta.

Hadinoto, Kusudianto 1996, Perencanaan Pengembangan Destinasi Pariwisata, Universitas Indonesia, Jakarta.
Inskeep, Edward 1991, Tourism Plannning "An Integrated and Sustainable Development Approach, Van Nostrand Reinhold, New York.

Kaussen, Valerie 2015, Zooming In: Virtual Disaster Tourism in PostEarthqueake Haiti, Social and Economic Studies 64: 3\&4 (2015): 33-78, ISSN: 0037-7651.

Kusmayadi dan Sugiarto 2002, Metodelogi Penelitian di Bidang Kepariwisataan, Gramedia Pustaka Utama, Jakarta.

Kotler, Philip dan Kevin Lane Kenner 2009, Manajemen Pemasaran Jilid 1 dan 2, Erlangga, Jakarta.

Lupiyoadi, Rambat dan A. Hamdani 2008, Manajemen Pemasaran Jasa, Salemba Empat, Jakarta.

Manolis (TRAVELSAT) 2011, Top Factors Influencing Destination Choice.

Marpaung, Happy 2000, Pengetahuan Kepariwisataan, Alfabeta, Bandung.

Mata-Lima, Herlander, Andreilcy AlvinoBorba, Adilson Pinheiro, Abel MataLima, and José António Almeida 2013, Impacts of Natural Disasters on Environmental and SocioEconomic Systems: What Makes the Difference? Ambiente \& Sociedade N São Paulo V. XVI, N. 3 N P. 4564 N Jul.-Set. 2013.

Mathieson, A dan Wall, G 1982, Tourism: Economic, Physical and Social Impact, Pitman Publishing, Oxport.

McIntyre, George 1993, Sustainable Tourism Development: Guide for Local Planners, World Tourism Organization, Spain.

Middleton, Victor T.C 1998, Sustainable Tourism: A Marketing Perspective, Butterworth Heinemann, Oxford. 
Mohamad, Daud dan Rozana Mohd Jamil 2012, A Preference Analysis Model for Selecting Tourist Destination Based on Motivational Factors: A Case Study in Kedah, Malaysia, Procedia - Social and Behavioral Sciences 65 (2012) 20 - 25.

Natori, Nasahiko (ed) 2001, A Guide Book for Tourism Based Community Development, Publisher APTE.

Pitana, I Gde 1999, Pelangi Pariwisata Bali, Bali Post, Denpasar.

Pitana, I Gde 2006, Kepariwisataan Bali Dalam Wacana Otonomi Daerah, Puslitbang Kepariwisataan, Jakarta.

Pitana, I Gde dan I Ketut Surya Diarta 2009, Pengantar Ilmu Pariwisata, Andi, Yogjakarta.

Seyidov, Javid dan Roma Adomaitiene 2016, Factors Influencing Local Tourists' Decision-Making on Choosing a Destination: a Case of Azerbaijan, Journal Ekonomika 2016 Vol. 95(3).

Soekadijo, R.G 1997, Anatomi Pariwisata (Memahami Pariwisata Sebagai Systemic Linkage), Gramedia Pustaka Utama, Jakarta.

Suwantoro, Gamal 2001, Dasar - Dasar Pariwisata, Andi, Yogjakarta.

Suwena, I Ketut dan I Gusti Ngurah Widyatmaja 2010, Pengetahuan Dasar Ilmu Pariwisata, Udayana University Press, Denpasar.

Tjiptono, Fandy dan Gregorius Chandra 2011, Pemasatan Strategik, Andi, Yogjakarta.

Tempo 2017.

https://m.tempo.co/read/news/2017/0 9/15/058909414/begini-sejarahletusan-gunung-agung-di-bali).

Wall, Geoffrey and Alister Mathieson 2006, Tourism: Change, Impacts and Opportunities, Pearson Prentice Hall. 